\title{
SOLVENCY EFFECTS OF TAXATION: A COMPARISON OF HUNGARIAN BANKS AND INSURANCE COMPANIES
}

\author{
Borbála SZÜLE \\ (Received: 15 January 2016; revision received: 6 November 2016; \\ accepted: 10 December 2016)
}

\begin{abstract}
Recently, there has been a growing interest in the solvency of financial intermediaries. Bank and insurer insolvency cases generated numerous adverse economic effects and also promoted academic efforts to design solvency-related taxation methods. The focus of this paper is on corporate taxation and its empirical relation to solvency in the Hungarian financial intermediation sector. Based on the previous literature, a complex empirical model of the interactions between capital formation, asset growth and solvency risk is presented, and panel data results are compared for banks and insurance companies. A comparison with international empirical results is also possible, although it may only be of limited relevance due to some differences in solvency measurement. The paper also aims to highlight the potential differences between banking and insurance. As far as solvency effects are concerned, the empirical results do not reveal significant differences in these two sectors; however, other results point to the heterogeneity of the Hungarian financial intermediation sector.
\end{abstract}

Keywords: banking, insurance, business tax, panel data

JEL classification indices: C23, G21, G22, H25

Borbála Szüle, Associate Professor at the Insurance Education and Research Group, Corvinus University of Budapest. E-mail: borbala.szule@uni-corvinus.hu 


\section{INTRODUCTION}

There is an ongoing debate about optimal taxation in the financial intermediation sector. Current academic research efforts focus mainly on the relationship of solvency and taxation when exploring possible methods for maintaining financial stability (e.g. IMF Staff 2010). Developments in regulation such as Basel III for banks and Solvency II for insurance companies also underline the importance of solvency in the financial system (e.g. ECB 2007, 2014; Jobst et al. 2014).

Taxation is a significant factor that can impact solvency. As indicated by some studies (e.g. Luo - Tanna 2014), corporate income taxation may have had an indirect effect on the international financial crisis of 2007-2009 owing to the asymmetric tax treatment of debt and equity on the capital structures of financial institutions. Yet, current literature about the effects of corporate income taxation on the solvency of financial intermediaries is quite limited.

Empirical evidence about the risk effects of taxation is mixed and depends also on the applied methodology. While some empirical results suggest that an increase in bank corporate taxes may decrease bank risk (de Nicolò 2010), other studies report that the risk reducing effects of taxation are not robust (e.g. CapelleBlancard - Havrylchyk 2013; Horváth 2013; Luo - Tanna 2014). Previous results are primarily related to the banking sector; possible similar effects in other components of the financial intermediation sector such as the insurance industry for example, have not yet been thoroughly examined.

In this paper, a modified version of the model in de Nicolò (2010) is applied to explore the solvency risk effects of taxation. De Nicolò (2010) aims at measuring the potential effect of a Financial Stability Contribution Tax and a Financial Activity Tax (proposed by IMF Staff 2010 as possible forms of contribution from the financial sector) on bank asset growth and banks' probability of default. As de Nicolò (2010) argues, an increase in bank corporate taxes is likely to have a negative effect on bank asset growth (with lower returns discouraging investments) and may adversely affect capital formation as well, and thus a negative impact on bank risk is also possible. These forecasting models are applied in the paper with a modification concerning the definition of risk measure.

To highlight heterogeneity within the financial intermediation sector, the paper examines Hungarian banking and insurance data separately. Balanced panel data covers the period of 1995 to 2013 for both sectors. Our intention was to perform a whole sector analysis by including the maximum possible number of institutions. This requirement resulted in the inclusion of 22 commercial banks and 18 insurance companies in the analysis. Due to market developments (e.g. the entrance of new firms into the financial industry), the share of included data to all data var- 
ies during the examination period, with a high percentage of total assets, equity, deposits (for banking sector), and reserves (for insurance sector) being included in the analysis. In 2013, the included total assets represented 76 per cent and 83 per cent of industry assets for banking and insurance, respectively. For that year, the panel data represent 78 per cent of the total equity in banking and 80 per cent in the insurance industry. In the banking sector, the share of included total deposits to all bank deposits is 77 per cent for 2013, while in the insurance sector, the ratio of included and all reserves (for unit-linked and other insurance products together) is 83 per cent for the same year.

According to our results, corporate taxation did not have a significant effect on asset growth (and thus on risk), neither for banks, nor for insurance companies. This result differs from those in de Nicolò (2010), but partly resembles the findings of Capelle-Blancard - Havrylchyk (2013), Horváth (2013), and Luo - Tanna 2014. Compared to the results in de Nicolò (2010), some other differences may also be observed in the forecasting models of capital formation and asset growth. Another finding of the paper is that Hungarian banking and insurance sector effects exhibit certain differences.

The paper is organised as follows. Section 2 describes the relevant literature and introduces the methodology. Section 3 discusses empirical results (with a comparison of the Hungarian banking and insurance sector). Section 4 summarises the main conclusions of the paper.

\section{METHODOLOGY AND DATA}

Recent financial system developments have fostered research about optimal taxation methods for financial intermediaries such as banks and insurance companies. Among other possible options for a "fair and substantial contribution by the financial sector", a report proposed Financial Stability Contribution (FSC) and Financial Activities Tax (FAT) as forms of contribution from the financial sector (IMF Staff 2010). This report advocated that FSC could be primarily paid for the fiscal cost of any future government support to the financial sector, and FAT could take up a role similar to value-added tax that is usually applied for the corporate sector (Cannas et al. 2014). The potential effects of these taxation methods have been examined separately for banks and insurance companies (for FSC, see IMF Staff 2010), or only for banks (for FSC and FAT, see de Nicolò 2010; Cannas et al. 2014).

Banks have a long history as performing financial intermediation activities (e.g. Allen - Santomero 1998; Diamond 1984), but in recent years, the financial 
landscape changed considerably, triggering also a transformation of activities in non-bank financial institutions (Scholtens - van Wensveen 2000). In previous research, banks have been generally considered as financial intermediaries (e.g. Mérö 2004), but currently insurance companies also play an important role in financial intermediation and the insurance industry can have systemic risks as well, as described, for example, by Schwarcz - Schwarcz (2014). Despite certain similarities (e.g. Briys - de Varenne 1995), some of the main features of insurers differ significantly from those of banks (e.g. OWC 2001; Morrison 2003; BIS 2011). A distinction between banks and insurance companies has already also been made in the taxation literature, for example when examining Financial Stability Contribution as a resolution mechanism that could reflect the systemic risk contributions of individual institutions (IMF Staff 2010).

A tax system can be very complex since in an optimal case, the various desirable attributes of taxation should be balanced (e.g. Slemrod 1990; Alm 1996). Although tax incidence may prevail in corporate taxation as well (Harberger 1962), the traditional goal of a tax on corporate income has been to raise tax revenues as efficiently as possible (Devereux - Sørensen 2006). There are several alternative views of the "classical" corporate tax system (e.g. Sørensen 1995) and corporate taxation is associated with various features of a firm (e. g. Modigliani - Miller 1958, 1963). It has to be emphasised that the aforementioned FSC and FAT are not equivalent to corporate taxes, although their potential effects have been measured with the application of corporate taxation data in the literature (de Nicolò 2010). According to the IMF Staff (2010), the main component in FSC would be paid for the fiscal cost of any future government support to the financial sector, so that also the tax base for banks and insurance companies could differ and FAT could take up a role similar to the value-added tax that is usually applied for the corporate sector (Cannas et al. 2014) and could be a tax on the sum of profits and remuneration in the financial sector (Keen et al. 2010). In practice, the corporate tax base may be related to corporate income earned (although the definition of the tax base can be quite complex; Devereux - Sørensen 2006).

In this paper, the results of taxation effects are calculated in a complex empirical model that is similar to that of de Nicolò (2010). A quantitative estimate of the impact of a given increase in corporate taxation is obtained with the application of forecasting models (for equity formation, bank asset growth, and the probability of bank default) and, in addition to this, with projections about bank asset growth change-related variations in GDP growth. A simplified structure of this estimation model is presented in Figure 1. 


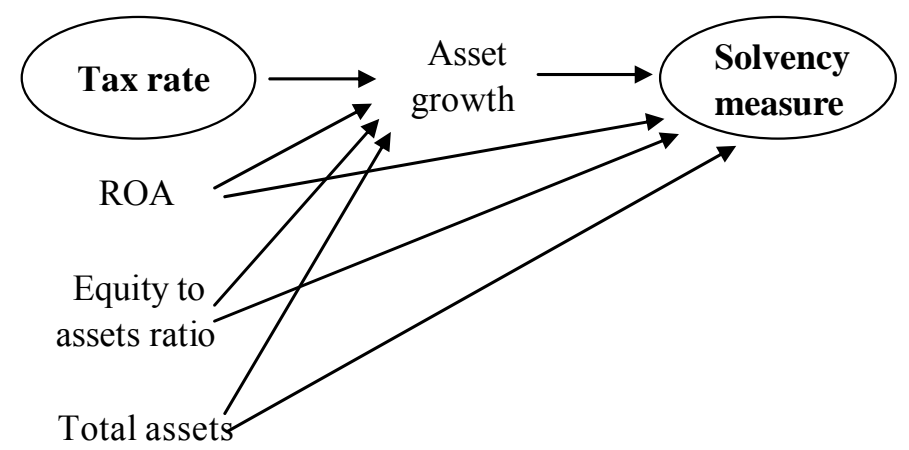

Figure 1. Simplified model structure

This paper focuses only on the institution-level impacts of corporate taxation. ${ }^{1}$ The forecasting models for capital formation, asset growth, and probability of default are described by the following equations in de Nicolò (2010):

$$
\begin{gathered}
\Delta E A_{i t} \equiv E A_{i t}-E A_{i t-1}=\alpha_{i}^{E}+\beta_{1}^{E} \cdot R O A_{i t-1}+\gamma^{E} \cdot \ln A_{i t-1}+\varepsilon_{i t} \\
A G_{i t}=\alpha_{i}^{G}+\beta_{1}^{G} \cdot T B_{i t-1}+\beta_{2}^{G} \cdot R O A_{i t-1}+\beta_{3}^{G} \cdot E A_{i t-1}+\gamma^{G} \cdot \ln A_{i t-1}+\theta_{i t} \\
B S M_{i t}=\alpha_{i}^{R}+\beta_{1}^{R} \cdot A G_{i t-1}+\beta_{2}^{R} \cdot R O A_{i t-1}+\beta_{3}^{R} \cdot E A_{i t-1}+\gamma^{R} \cdot \ln A_{i t-1}+\eta_{i t}
\end{gathered}
$$

where $E A_{i t}$ indicates the ratio of book equity to assets, $A G_{i t}$ indicates bank asset growth, $T B_{i t}$ denotes the effective tax rate, $A_{i t}$ indicates total assets, and the aftertax return on assets is indicated by $R O A_{i t}$. In Equation (3), the Black-Scholes probability of default is denoted by $B S M_{i t}$ (with $i$ and $t$ indicating a given bank and a given year in the analysis).

In de Nicolò's (2010) model, corporate taxation may influence asset growth as described by Equation (2), with the effective tax rate being defined as the ratio of corporate taxes to pre-tax profits. In the previous literature, the definition of tax measure proved to be essential in influencing the statistical significance of empirical results. For example, Luo - Tanna (2014) present two alternative corporate tax measures (corporate income tax rate and implicit tax rate, defined as the ratio of tax expenses over profit before tax), and their results suggest that there is

One of the limitations of the paper is that although the exploration of solvency effects could benefit from a more complex model structure, a detailed analysis of the relationship of bank asset growth and macroeconomic factors (such as GDP growth) is not included in the paper. The lack of the modelling of competition (that theoretically may also be related to the risk of bank failures, as described by for example Martinez-Miera - Repullo (2010)) is another limitation of the paper. 
a statistically significant and negative relationship between corporate income tax rate and the bank risk-taking measure when the statutory corporate income tax rate is used as a proxy for taxation. However, when the implicit tax rate is used as a proxy for taxation, the effect of taxation on risk-taking is only significant in a static model, but in a dynamic specification (when the first lag of the risk-taking measure is also included in the estimation), this effect is not significant. CapelleBlanchard - Havrylchyk (2013) argue that a reason for applying implicit tax rate in empirical studies may be that the statutory corporate income tax rate does not necessarily reflect the real burden of taxation (since the amount of tax that companies pay may depend also on specific fiscal rules and other factors that may influence the tax base). In this paper, the tax measure is defined as an effective tax rate (as the ratio of corporate taxes to pre-tax profits, according to the definition in de Nicolò 2010).

Our forecasting model also differs from that in de Nicolò (2010) through the definition of solvency. In de Nicolò (2010), bank risk is measured by the BlackScholes-Merton probability of default (with higher values indicating higher solvency risk), while in this paper, an accounting-based solvency measure is applied (with higher values indicating lower solvency risk). The application of the BlackScholes-Merton probability of default (or alternatively, the so-called distanceto-default) as a risk measure is quite common in the literature (e.g. BlundellWignall - Roulet 2013; Breig - Elsas 2009). The theoretical background for the calculation of this risk measure is provided by the option pricing model described in Black - Scholes (1973), in which a firm's equity may be viewed as a call option on the firm's assets, and corporate liabilities can also be viewed as options. In the Black-Scholes model, the probability of default can be calculated after the quantification of assets and the standard deviation of assets (this calculation step may require complex methodology and market data). The so-called distance-todefault, resulting from a relatively simple transformation of the probability of default, measures how many standard deviations the asset value needs to drop to meet the debt value (Breig - Elsas 2009). In this paper, (daily) market observations are not available for all companies in the database, thus another measure is calculated to quantify the stability of banks and insurance companies. Similarly to other studies (e.g. Laeven - Levine 2009; Horváth 2013; Luo - Tanna 2014), a $\mathrm{Z}$-score is calculated to measure stability:

$$
Z=\frac{R O A+E / A}{\sigma(R O A)} .
$$

In Equation (4), ROA is the return on assets, $\sigma(\mathrm{ROA})$ indicates the standard deviation of ROA values, and $E / A$ is the equity to total assets ratio. The higher 
value of this $\mathrm{Z}$-score measure indicates lower insolvency risk and hence may be considered as a measure of the overall stability of an institution.

In our paper, the maximum possible amount of data is applied to estimate standard deviation of ROA. This means that (due to necessary transformations of data) although the balanced panel data cover the period of 1995 to 2013, data in the period of 1993 to 2013 are used to estimate standard deviation of return on assets. Similarly to the previous literature (e.g. Horváth 2013), the natural logarithm of the Z-score measure is applied. As demonstrated by Table 1, logarithmisation results in a decreasing (and closer to zero) skewness measure for both banking and insurance sector data (thus indicating a more symmetric distribution after logarithmisation).

By applying the logarithmised solvency measure, the estimated model for solvency effects is described by Equation (5):

Table 1. Effect of logarithmisation on the skewness measure

\begin{tabular}{lll} 
& $\mathrm{Z}$ score & $\ln \mathrm{Z}$ \\
\hline banking & 1.252 & -0.442 \\
insurance & 0.841 & -0.647 \\
\hline
\end{tabular}

$$
\ln Z_{i t}=\alpha_{i}^{R}+\beta_{1}^{R} \cdot A G_{i t-1}+\beta_{2}^{R} \cdot R O A_{i t-1}+\beta_{3}^{R} \cdot E A_{i t-1}+\gamma^{R} \cdot \ln A_{i t-1}+\eta_{i t} .
$$

In order to keep the size of the database as large as possible, only those institutions are excluded from the analysis that had no tax payment in the balance sheets in the observed period, or the natural logarithm of the Z-score could not be adequately calculated. With these exclusions, the analysis includes $22 \mathrm{com}$ mercial banks and 18 insurance companies. The publicly available accounting (balance sheet and profit statement) data are from the homepage of the central bank of Hungary (MNB).

It should be noted that compared to de Nicolò (2010), one of the key differences is that this paper also presents insurance sector-related results, as a comparison of banking and insurance results may provide an interesting insight into the diversity of the financial system.

As Shackelford et al. (2010) point out, the potential "distribution" of the tax burden may also be an interesting research subject. It belongs to the limitations of our paper that tax incidence effects are not analysed (although it may also be a relevant question since price elasticities of demand and supply are not readily observable in the financial sector and thus are relatively complex to model. See Weder di Mauro 2010). 


\section{EMPIRICAL RESULTS}

The estimated forecasting model for capital formation in de Nicolò (2010), described by Equation (1), suggests that a change in after-tax returns may theoretically influence the expansion of investments and capital formation. Table 2 shows the results of this forecasting model for the Hungarian commercial banking and insurance sector. The results in Table 2 are estimated with a fixed effects model for both sectors (with time dummies for banking sector data and without time dummies for insurance sector data, by applying only significant time dummies).

The debate about the choice between fixed effects and random effects estimators has a long history in econometric literature. Nerlove - Balestra (1992) suggest that fixed effects models are appropriate, if a population is sampled exhaustively or if the prediction of individual behaviour is needed. Wooldridge (2010: 286) argues that the key issue is whether or not the unobserved effect is uncorrelated with the observed explanatory variables. As emphasised also by Baltagi et al. (2003), the decision about the choice of fixed effects or random effects models may be based on the results of the standard Hausman test (about the conditional mean of the disturbances given the regressors being zero). In the following, results of the Hausman test are applied for the choice between the fixed effects and random effects estimators. The empirical significance level for the Hausman test is below 0.02 in case of both analyses in Table 2 .

Return on assets has a significant (increasing) effect on capital formation of banks in de Nicolò (2010). For Equation (1), the empirical results reveal a significant difference between the results in de Nicolò (2010) and the analysis of Hungarian commercial banking sector data (where this effect is not significant). The results for the Hungarian insurance sector data are similar to those in de Nicolò (2010), but the estimated coefficient for return on equity is higher, and the other estimated coefficients also differ. The results for the Hungarian commercial banking sector show that past return did not have a significant effect on capital formation.

Table 2. Forecasting model for capital formation

\begin{tabular}{lcc} 
& Banking & Insurance \\
\hline ROA $(\mathrm{t}-1)$ & 0.0795 & 0.5121 \\
& $(0.6568)$ & $(0.0000)$ \\
$\ln \mathrm{A}(\mathrm{t}-1)$ & 0.0428 & 0.0305 \\
& $(0.0000)$ & $(0.0007)$ \\
constant & -0.5586 & -0.5386 \\
& $(0.0000)$ & $(0.0005)$ \\
\hline
\end{tabular}

Source: Own calculations (p-values in parentheses). 
In de Nicolò (2010), corporate taxation has a negative effect on capital formation and asset growth, and also increases bank risk (measured by the BlackScholes-Merton probability of default). The effective tax rate appears in Equation (2) in the model, and according to the results in de Nicolò (2010), the effective tax rate has a significant negative impact on asset growth. Table 3 shows estimation results (calculated with a fixed effects model with time dummies) in the case of Equation (2). The results in Table 3 differ significantly from those in de Nicolò (2010), since the estimated coefficient belonging to the effective tax rate does not significantly differ from zero (neither for banking sector data, nor for the insurance sector).

Table 3. Forecasting model for asset growth

\begin{tabular}{lcc} 
& Banking & Insurance \\
\hline TB(t-1) & 0.0025 & 0.0521 \\
& $(0.9848)$ & $(0.5359)$ \\
ROA $(\mathrm{t}-1)$ & 2.835 & 0.1213 \\
& $(0.0463)$ & $(0.7123)$ \\
$\mathrm{EA}(\mathrm{t}-1)$ & -1.4187 & 0.3904 \\
& $(0.0359)$ & $(0.0235)$ \\
$\ln \mathrm{A}(\mathrm{t}-1)$ & -0.5268 & -0.1921 \\
& $(0.0000)$ & $(0.0000)$ \\
constant & 6.9589 & 3.3037 \\
& $(0.0000)$ & $(0.0000)$ \\
\hline
\end{tabular}

Source: Own calculations (p-values in parentheses).

Similarly to Equation (1), the estimation results for the forecasting model in Equation (2) also reveal interesting differences between banking and insurance sector results. The effect of equity to asset ratio increase is significant, but opposite in these two sectors: while an increase in the equity to asset ratio ("increased capital") increases asset growth in the insurance sector (similarly to the result in de Nicolò 2010), it has a decreasing effect on asset growth in the commercial banking sector.

Table 4 presents the estimation results for Equation (5), with the natural logarithm of the Z-score in Equation (4) being the solvency risk measure in the model. In this case, a random effects model was applied, as the p-values of the Hausman test were above 0.5 in both analyses. In the case of insurance sector data, time dummies were applied, but (due to the lack of overall significance) time dummies were not used for commercial banking sector data.

A major difference between the results of de Nicolò (2010) and ours is that taxation does not seem to have a significant impact on solvency risk. Since effective tax rate does not influence asset growth, an effect of taxation on solvency 
Table 4. Forecasting model for solvency risk

\begin{tabular}{lcc} 
& Banking & Insurance \\
\hline ROA $(\mathrm{t}-1)$ & 4.8257 & 2.6766 \\
& $(0.0006)$ & $(0.0002)$ \\
$\mathrm{EA}(\mathrm{t}-1)$ & 3.1911 & 1.0457 \\
& $(0.0000)$ & $(0.0031)$ \\
$\ln \mathrm{A}(\mathrm{t}-1)$ & 0.0376 & 0.0165 \\
& $(0.5375)$ & $(0.8017)$ \\
$\mathrm{AG}(\mathrm{t}-1)$ & -0.0100 & -0.0543 \\
& $(0.9056)$ & $(0.6127)$ \\
constant & 1.4286 & 1.2040 \\
& $(0.0859)$ & $(0.3179)$ \\
\hline
\end{tabular}

Source: Own calculations (p-values in parentheses).

risk (through asset growth) is not significant, neither for Hungarian commercial banking, nor for the insurance sector data. It is also interesting that asset growth does not have a significant effect on the solvency risk measure either (although this effect is significant in de Nicolò 2010).

As far as differences between commercial banking and insurance sector are concerned, the estimation results for Equation (3) are quite similar in these two sectors: for example, an increase in the return on assets or in the equity to asset ratio significantly increases solvency in both sectors.

\section{CONCLUSIONS}

The solvency of financial intermediaries received increased attention in the aftermath of the recent international financial crisis. Numerous studies examined how solvency could be strengthened and strove to discover ways to decrease insolvency risk when possible interactions of taxation and solvency are also considered. This paper aimed to contribute to the previous literature by analysing some aspects of this relationship based on panel data of Hungarian commercial banks and insurance companies. The contribution of the paper is partly related to the empirical model construction and partly to a comparison of banking and insurance sector results.

The forecasting models for capital formation, asset growth, and solvency risk are similar to those in de Nicolò (2010), although with a major difference that concerns the definition of risk. Instead of using the (partly market data-based) Black-Scholes-Merton probability of default as a risk measure, the paper applies (similarly to some other studies) an accounting data-based solvency measure. 
With the analysis of a large unbalanced panel of US banks during 1995-2009, de Nicolò (2010) assessed the potential impact of different levels of proposed tax alternatives on bank asset growth and banks' probability of default by concluding that these effects are negative, but quantitatively small. Compared to these results, the most important result is that (in contrast to the results in de Nicolò 2010), no significant effect of the taxation on solvency risk could be found with panel data analysis, either for the Hungarian commercial banking sector, or for the Hungarian insurance sector.

The empirical analysis also revealed interesting differences between the banking and insurance sector. Some insurance sector results (for example related to the effect of returns on capital formation) are similar to those in de Nicolò (2010), while the corresponding results for the commercial banking sector (about the capital formation effect of returns) differ significantly.

Our results indicate that regarding the relationship of asset growth and capital formation, the Hungarian financial intermediation sector cannot be considered as homogeneous. However, as far as the relationship of taxation and solvency is concerned, Hungarian commercial banking and insurance results are quite similar.

There are several ways in which the presented model could be developed. Directions for future research include the modelling of tax incidence and a more thorough analysis of the relationship of bank asset growth and macroeconomic factors.

\section{REFERENCES}

Allen, F. - Santomero, A. M. (1998): The Theory of Financial Intermediation. Journal of Banking \& Finance, 21: 1461-1485.

Alm, J. (1996): What is an "Optimal” Tax System? National Tax Journal, 49(1): 117-133.

Baltagi, B. H. - Bresson, G. - Pirotte, A. (2003): Fixed Effects, Random Effects or HausmanTaylor? A Pretest Estimator. Economics Letters, 79: 361-369.

Bank for International Settlements (BIS) (2011): Fixed Income Strategies of Insurance Companies and Pension Funds. Committee on the Global Financial System - CGFS Papers, No. 44.

Black, F. - Scholes, M. (1973): The Pricing of Options and Corporate Liabilities. The Journal of Political Economy, 81(3): 637-654.

Blundell-Wignall, A. - Roulet, C. (2013): Business Models of Banks, Leverage and the Distanceto-Default. OECD Journal: Financial Market Trends. Volume 2012/2.

Breig, C. - Elsas, R. (2009): Default Risk and Equity Returns: A Comparison of the Bank-Based German and the U.S. Financial System. Munich School of Management, University of Munich, Discussion Paper, No. 2009-12.

Briys, E. - De Varenne, F. (1995): On the Risk of Life Insurance Liabilities: Debunking Some Common Pitfalls. Wharton Financial Institutions Center, Working Paper, No. 96-29, University of Pennsylvania. http://Fic.Wharton.Upenn.Edu/Fic/Papers/96/9629.pdf 
Cannas, G. - Cariboni, J. - Marchesi, M. - Nicodème, G. - Giudici, M. P. - Zedda, S. (2014): Financial Activities Taxes, Bank Levies and Systemic Risk. European Commission, Taxation Papers, Working Paper, No. 43.

Capelle-Blancard, G. - Havrylchyk, O. (2013): The Ability of Banks to Shift Corporate Income Taxes to Customers. CEPII Working Paper, No.2013-09.

de Nicolò, G. (2010): The Potential Impact of FSC and FAT on Bank Asset Growth, Risk, and Real Activity. In Claessens, S. - Keen, M. - Pazarbasioglu, C. (eds): Financial Sector Taxation, the IMF's Report to the G-20 and Background Material, pp. 188-191. International Monetary Fund.

Devereux, M. P. - Sørensen, P. B. (2006): The Corporate Income Tax: International Trends and Options for Fundamental Reform. Economic Papers, No. 264. European Commission DirectorateGeneral for Economic and Financial Affairs.

Diamond, D. W. (1984): Financial Intermediation and Delegated Monitoring. The Review of Economic Studies, 51(3): 393-414.

ECB (2007): Potential Impact of Solvency II on Financial Stability. July. https://Www.Ecb.Europa. $\mathrm{Eu} / \mathrm{Home} / \mathrm{Html} / \mathrm{Search}$. En.Html?Q=Potential Impact of Solvency II.

ECB (2014): Financial Stability Review. May.

Harberger, A. C. (1962): The Incidence of the Corporation Income Tax. The Journal of Political Economy, 70(3): 215-240.

Horváth, B. (2013): The Impact of Taxation on Bank Leverage and Asset Risk. CentER Discussion Paper, No. 2013-076. Tilburg University.

IMF Staff (2010): A Fair and Substantial Contribution by the Financial Sector. In: Claessens, S. Keen, M. - Pazarbasioglu, C. (eds): Financial Sector Taxation, The IMF's Report to the G-20 and Background Material, pp. 2-73. IMF.

Jobst, A. A. - Sugimoto, N. - Broszeit, T. (2014): Macroprudential Solvency Stress Testing of the Insurance Sector. IMF Working Paper, WP/14/133.

Laeven, L. - Levine, R. (2009): Bank Governance, Regulation and Risk Taking. Journal of Financial Economics, 93(2): 259-275.

Luo, Y. - Tanna, S. (2014): Taxation and Bank Risk-Taking. In: Chaudhry, S. M. - Mullineux, A. W. (eds): Taxing Banks Fairly. Cheltenham: Edward Elgar.

Keen, M. - Krelove, R. - Norregaard, J. (2010): The Financial Activities Tax. In: Claessens, S. Keen, M. - Pazarbasioglu, C. (eds): Financial Sector Taxation, The IMF's Report to the G-20 and Background Material, pp. 118-143. International Monetary Fund.

Martinez-Miera, D. - Repullo, R. (2010): Does Competition Reduce the Risk of Bank Failure? The Review of Financial Studies, 23(10): 3638-3664.

Mérö, K. (2004): Financial Depth and Economic Growth - The Case of Hungary, the Czech Republic and Poland. Acta Oeconomica, 54(3): 297-321.

Modigliani, F. - Miller, M. H. (1958): The Cost of Capital, Corporation Finance and the Theory of Investment. The American Economic Review, 48(3): 261-297.

Modigliani, F. - Miller, M. H. (1963): Corporate Income Taxes and the Cost of Capital: A Correction. The American Economic Review, 53(3): 433-443.

Morrison, A. D. (2003): The Economics of Capital Regulation in Financial Conglomerates. The Geneva Papers on Risk and Insurance, 28(3): 521-533.

Nerlove, M. - Balestra, P. (1992): Formulation and Estimation of Econometric Models for Panel Data. In: Mátyás, L. - Sevestre, P. (eds): The Econometrics of Panel Data. Handbook of Theory and Applications. Dordrecht, the Netherlands: Kluwer Academic Publishers.

OWC (2001): Study on the Risk Profile and Capital Adequacy of Financial Conglomerates. Oliver, Wyman \& Company. 
Scholtens, B. - Van Wensveen, D. (2000): A Critique on the Theory of Financial Intermediation. Journal of Banking \& Finance, 24(8): 1243-1251.

Schwarcz, D. - Schwarcz, S. L. (2014): Regulating Systemic Risk in Insurance. The University of Chicago Law Review, 81(4): 1569-1640.

Shackelford, D. A. - Shaviro, D. N. - Slemrod, J. (2010): Taxation and the Financial Sector. National Tax Journal, 63(4, Part 1): 781-806.

Slemrod, J. (1990): Optimal Taxation and Optimal Tax Systems. The Journal of Economic Perspectives, 4(1): 157-178.

Sørensen, P. B. (1995): Changing Views of the Corporate Income Tax. National Tax Journal, 48(2): 279-294.

Weder di Mauro, B. (2010): Quantitative Impact of Taxing or Regulating Systemic Risk. In: Claessens, S. - Keen, M. - Pazarbasioglu, C. (eds): Financial Sector Taxation, The IMF's Report to the G-20 and Background Material, pp. 96-105. International Monetary Fund.

Wooldridge, J. M. (2010): Econometric Analysis of Cross Section and Panel Data. 2nd edition. Cambridge: The MIT Press. 